\title{
A SINGLE ASSAY FOR SIMULTANEOUSLY TESTING EFFECTORS OF ALANINE RACEMASE AND/OR D-ALANINE: D-ALANINE LIGASE
}

\author{
Pasquale P. Vicario, Barbara G. Green and Howard M. Katzen* \\ Department of Biochemical Endocrinology, \\ Merck Institute for Therapeutic Research, \\ P.O. Box 2000, Rahway, New Jersey 07065, U.S.A. \\ (Received for publication September 22, 1986)
}

\begin{abstract}
The biosynthesis from L-alanine of D-alanyl-D-alanine, required for the peptidoglycan layer of the cell wall of many bacterial species, is catalyzed by two enzymes in series, alanine racemase and D-alanine: D-alanine ligase. A simple in vitro method, called the combined assay, for simultaneously testing for effectors of either or both enzymes in a single assay by coupling these enzymes to each other is described here. The experiments used to derive the optimum conditions for the assay are also described. Each enzyme is included in the assay in rate-limiting amounts, wherein the product of the initial racemase reaction, $\mathrm{D}$-alanine, becomes the substrate for the subsequent ligase. The product of the overall reaction, $\left[{ }^{14} \mathrm{C}\right]-$ $D$-alanyl-D-alanine, is separated chromatographically from the $\mathrm{L}-\left[1{ }^{14} \mathrm{C}\right]$ alanine substrate, and from any $\mathrm{D}-\left[1{ }^{-14} \mathrm{C}\right]$ alanine intermediate, at the end of the incubation, is counted and the percent conversion of substrate to product calculated. The inhibitory effects of 3-fluoro-Dalanine-2 $d$, a known inhibitor of the racemase, and D-cycloserine and DL-1-aminoethylphosphonic acid, inhibitors of both enzymes, were readily detectable. The sensitivity of the combined assay to these inhibitors appears similar to that of earlier assays. This assay has the advantage over previous ones of being able to detect inhibitors of either enzyme in a single assay, thereby avoiding the need to screen each compound in a separate assay of each enzyme.
\end{abstract}

Alanine racemase (EC 5.1.1.1) and D-alanine: D-alanine ligase (ADP) (EC 6.3.2.4), the latter sometimes referred to as D-alanyl-D-alanine (D-Ala-D-Ala) synthetase, are the enzymes that catalyze the formation of D-Ala-D-Ala from L-alanine. They constitute what has been called the alanine branch of the pathway for the biosynthesis of the peptidoglycan layer of cell walls in many bacterial species; for a recent review see Neuhaus and Hammes ${ }^{2)}$. Assays for the racemase reaction (see reaction 1 , below) in either direction, by measuring $\mathrm{L}$ - or $\mathrm{D}$-alanine formation, and for the ligase reaction (see reaction 2) by measuring the production of inorganic phosphate, ADP or dipeptide, have been devised and used routinely ${ }^{2,3)}$.

$$
\begin{gathered}
\text { L-alanine } \rightleftarrows \text { D-alanine } \\
2 \times \text { D-alanine }+ \text { ATP } \underset{\mathrm{Mg}^{++}}{\longleftrightarrow} \text { D-Ala-D-Ala }+ \text { ADP }+ \text { Pi }
\end{gathered}
$$

These assays have been employed in screening for inhibitors in vitro in the search for potential new anti-bacterial agents. The earlier discoveries of inhibitors of either or both of these enzymes, such as 3-fluoro-D-alanine ${ }^{4}$ 7) and D-cycloserine ${ }^{8,9)}$ stimulated a search in our laboratories for other such inhibitors. To facilitate this study, we devised an in vitro method capable of detecting inhibitors of either enzyme in a single assay. This new method, described here, is based upon the ${ }^{14} \mathrm{C}$-dipeptide chromatographic assay for the ligase previously developed by NeuHAus ${ }^{3)}$. The present method employs $\mathrm{L}-\left[{ }^{14} \mathrm{C}\right] \mathrm{alanine}$ as the substrate for the assay of both enzymes coupled to each other, both in ratelimiting amounts. In this system, the product of Reaction 1 becomes the substrate for Reaction 2 , 
and inhibitors of either or both enzymes become readily detectable. This assay has the advantage of avoiding the need for two separate assays in the test of each and every compound.

\section{Materials and Methods}

$\mathrm{L}-\left[1-^{-14} \mathrm{C}\right]$ Alanine and $\mathrm{D}-\left[1-^{-14} \mathrm{C}\right] \mathrm{alanine}$, of specific activities of 56.8 and $56.3 \mu \mathrm{Ci} / \mu \mathrm{mol}$, respectively, were purchased from ICN Pharmaceuticals, Radiochemical Division. D-Alanine, L-alanine, NADH and disodium ATP were obtained from Calbiochem. D-Amino acid oxidase (EC 1.4.3.3, 15 units $/ \mathrm{mg}$ ) and lactic dehydrogenase (EC 1.4.3.3, 450 units/mg) were products of Boehringer Mannheim. 3-Fluoro-D-alanine-2 $d$ was kindly provided by Drs. JANOS KollonitsCH and LouIs BARASH of the Merck Sharp \& Dohme Research Labs. DL-1-Aminoethylphosphonic acid and Dcycloserine were purchased from Sigma Chemical Co. All other reagents were obtained from the usual commercial sources. Protein was determined by the method of Lowny et al. ${ }^{10)}$.

Preparation and Assays of Individual Enzymes

Escherichia coli B cells, strain MB1967, were obtained from the Merck Sharp \& Dohme Stock Culture Collection. Cells were grown and harvested as described by WANG and WALSH ${ }^{2)}$. Alanine racemase was prepared from these celis using the modification by WANG and WALSH ${ }^{2)}$ of the procedure of LAMBERT and NeuHAus ${ }^{11}$. Enzyme was purified up to and including the first DEAE-Sephadex column step ${ }^{11)}$. This resulted in specific activities ranging from $8 \sim 12$ units/mg of protein among different batches. An unit of enzyme is defined as the amount that catalyzes the formation of $1 \mu \mathrm{mol}$ of product per minute at $22^{\circ} \mathrm{C}$. Racemase activity was assayed in the $\mathrm{L}$ to $\mathrm{D}$ direction (with $20 \mathrm{~mm}$ L-alanine) using the lactic dehydrogenase-D-amino acid oxidase-coupled spectrophotometric method of $W_{A N G}$ and $W_{A L S H}{ }^{2)}$. Using this procedure, we found a $\mathrm{Km}$ of approximately $1 \sim 1.5 \mathrm{mM}$ L-alanine which compares favorably with their value of $1.3 \mathrm{~mm}^{22}$.

Streptococcus faecalis $\mathrm{R}$ cells (ATCC 8043), obtained from the American Type Culture Collection, Rockville, Md., were grown and harvested according to the procedure of NeUHAUS ${ }^{3\rangle}$. D-Alanine: $\mathrm{D}$-alanine ligase was prepared from these cells by the purification procedure of NeUHAus ${ }^{32}$, up to and including the acetone precipitation step. The specific activity of the resultant preparation ranged from 60 to 90 units/mg of protein. A unit of ligase is defined as the amount of activity that catalyzes the formation of $1 \mu \mathrm{mol}$ of D-Ala-D-Ala per hour at $37^{\circ} \mathrm{C}$, using the ${ }^{14} \mathrm{C}$-dipeptide chromatographic separation method described by NeUHAUs $^{3)}$. According to this procedure, we found a $\mathrm{Km}$ of $3.7 \mathrm{~mm}$ D-alanine which may be compared with their value of $4.8 \mathrm{~mm}^{3}$.

Combination Assay for Alanine Racemase and D-Alanine: D-Alanine Ligase

The assay for the combination of racemase and ligase is an extension of the ${ }^{14} \mathrm{C}$-dipeptide procedure of NeuHaus ${ }^{3)}$ used to measure the conversion of $\mathrm{D}-\left[1-{ }^{14} \mathrm{C}\right]$ alanine to ${ }^{14} \mathrm{C}$-labeled D-Ala-D-Ala by the ligase. The present assay measures the conversion of $\mathrm{L}-\left[1-{ }^{14} \mathrm{C}\right]$ alanine to the ${ }^{14} \mathrm{C}$-labeled dipeptide by coupling the ligase to the racemase reaction. For convenience it is referred to as the "combined" assay. The assay mixture contained $8 \mathrm{mM} \mathrm{MnCl}_{2}, 10 \mathrm{mM} \mathrm{KCl}, 10 \mathrm{~mm}$ disodium ATP (adjusted with $\mathrm{NaOH}$ to $\mathrm{pH} 7.0$ ), $2.5 \mathrm{~mm}$ reduced glutathione, and designated amounts of each enzyme or a stock mixture of both enzymes in the standard assay (see text) in a final volume of $0.1 \mathrm{ml}$ Tris - $\mathrm{HCl}$ buffer, $\mathrm{pH} 7.8$. The reaction was started by the addition of $\mathrm{L}-\left[1-^{-14} \mathrm{C}\right]$ alanine $\left(2.0 \times 10^{6} \mathrm{dpm} / \mathrm{mol}\right)$ to a final concentration of $4 \mathrm{~mm}$ (unless designated otherwise). Assay mixtures were incubated for 30 minutes (unless noted otherwise) at $37^{\circ} \mathrm{C}$. The reaction was terminated by placing the assay tubes in a boiling water bath for 5 minutes.

Test compounds were incubated with a mixture of the two enzymes in $8 \mathrm{mM} \mathrm{MnCl}_{2}$ and $10 \mathrm{mM}$ $\mathrm{KCl}$ in a final volume of $0.080 \mathrm{ml}$ of buffer for 40 minutes at $20^{\circ} \mathrm{C}$ prior to the addition of the remaining components (in buffer containing the $\mathrm{MnCl}_{2}$ and $\mathrm{KCl}$ ) of the reaction mixture and the subsequent 30 minutes incubation described above.

After termination of the reaction, the resultant mixture was analyzed by descending paper chromatography essentially by the procedures, including counting the radioactive product, intermediate, and remaining radio-labeled substrate, described by NeuHaus ${ }^{3)}$. The amount of ${ }^{14} \mathrm{C}$-labeled dipeptide 
formed was calculated from the percentage conversion of $\mathrm{L}-\left[1-{ }^{14} \mathrm{C}\right] \mathrm{alanine}$ to labeled dipeptide. Percent conversion was calculated from the amount of radioactivity in the dipeptide region of the chromatograph divided by the total radioactivity in the incubation mixture times 100 . Total radioactivity equals the sum of the radioactivity in the free amino acid region (D-alanine co-chromatographs with L-alanine) plus that in the dipeptide region.

\section{Results and Discussion}

Enzyme Dose- and Incubation

Time-responses

The amount of each component enzyme in the assay system required to maintain limiting activities of each enzyme over a significant activity range was determined by a study of the dependency of the rate of ${ }^{14} \mathrm{C}$-dipeptide product formation on the concentration of each enzyme in the assay (Fig. 1). Until optimal conditions for the assay were subsequently determined (see below), the time of incubation initially used was selected from that previously used in the individual ligase assay ${ }^{3)}$ (i.e. 30 minutes). The concentration of L-alanine substrate employed in these experiments was $4 \mathrm{~mm}$. Higher concentrations of unlabeled substrate were found to reduce the specific radioactivity of the ${ }^{14} \mathrm{C}$-dipeptide product below the level of detectability.
Fig. 1. Dependency of the rate of ${ }^{14} \mathrm{C}$-dipeptide formation from $\mathrm{L}-\left[1-{ }^{14} \mathrm{C}\right] \mathrm{alanine}$ on the concentration of each enzyme in the combined assay.

A racemase preparation (containing about 9 units of activity per mg and $1.1 \mu \mathrm{g}$ of protein per liter) was titrated () in the presence of $65 \mu \mathrm{g}$ of the ligase preparation under the conditions used in the combined assay described in Materials and Methods. The ligase preparation (containing about 70 units $/ \mathrm{mg}$ and $3.25 \mu \mathrm{g}$ of protein per $\mu \mathrm{l})$ was titrated $(O)$ in the presence of $1.1 \mu \mathrm{g}$ of the racemase.

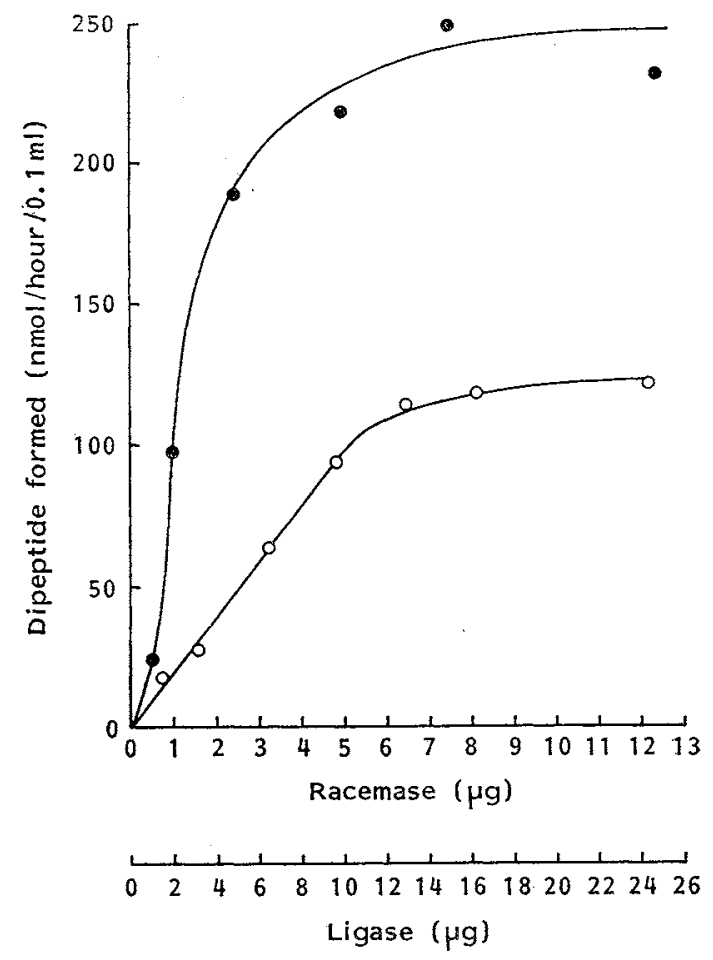

The dependency of the rate of the overall reaction on the concentration of alanine racemase was tested in the presence of a relatively high (compared to the amount of ligase subsequently used to test inhibitors, see below) concentration of the ligase $(65 \mu \mathrm{g})$ (Fig. 1). The rate of reaction was nearly maximal at concentrations of racemase exceeding $5 \mu \mathrm{g}$ (approximately 50 munits) per $0.1 \mathrm{ml}$ of final incubation medium. However, the dose-response increase in the rate began to decline significantly at about $3 \mu \mathrm{g}$ when the amount of Lalanine available most likely became limiting. At racemase levels exceeding $10 \mu \mathrm{g} / 0.1 \mathrm{ml}$, the available substrate had likely been nearly depleted during the 30-minute incubation period. To determine accurately how much substrate was, in fact, remaining after this period, repeated experiments were conducted with $13 \mu \mathrm{g}$ of enzyme per incubation volume (data not shown). It was calculated that greater than $175 \mathrm{nmol}$ of dipeptide were formed, and that, therefore, less than $50 \mathrm{nmol}$ or $12 \%$ of the initial $400 \mathrm{nmol}$ of substrate remained. Calculations were based upon a requirement of 2 mol of substrate for each mol of product formed. It should be noted in Fig. 1 that at the amounts of racemase below $1 \mu \mathrm{g}$, the dose-response curve appears upward-sloping rather than linear. 
Fig. 2. Effect of varying the concentration of both enzymes in the combination assay.

Varying aliquots of a stock enzyme solution containing $180 \mu \mathrm{g} / \mathrm{ml}$ of the racemase preparation and $2.5 \mathrm{mg} / \mathrm{ml}$ of the ligase preparation were tested in the assay.

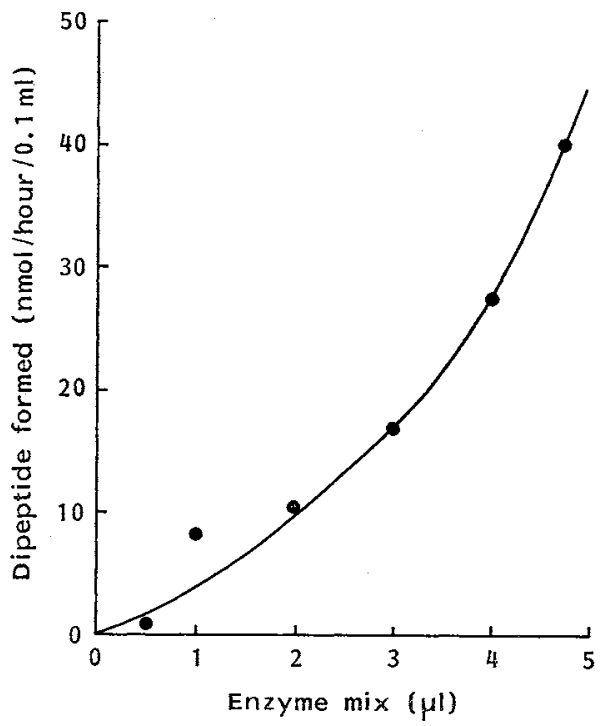

Further studies will be required to evaluate the significance of this observation.
Fig. 3. Dependency of dipeptide formation in the combination assay on the time of incubation.

Racemase at $1 \mu \mathrm{g}$ and ligase at $7 \mu \mathrm{g}$ were incubated for the designated periods of time with $20 \mathrm{~mm}(0)$ and $4 \mathrm{~mm}(\mathrm{O}) \mathrm{L}-\left[1-{ }^{-14} \mathrm{C}\right]$ alanine at $37^{\circ} \mathrm{C}$ as described in the Materials and Methods section, and the resultant amount of dipeptide found was determined.

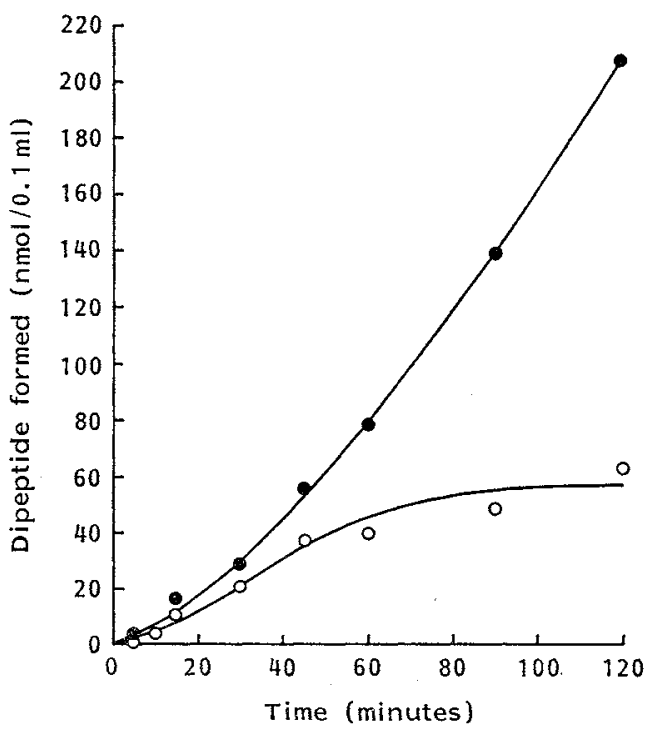

On the basis of the racemase dose-response seen in Fig. 1, about 1 to $1.3 \mu \mathrm{g}$ of the racemase preparation (i.e. approximately 10 munits) were selected for use in subsequent assays. At this concentration of racemase, the effect of varying the concentration of ligase was then tested (Fig. 1). The initial portion of the response was linear. That the maximum rate of reaction was limited to approximately $120 \mathrm{nmol}$ of dipeptide formed per hour at the highest concentration of ligase is consistent with the rate expected for the amount of racemase used in this titration (i.e. 1.1 $\mu \mathrm{g}$ ). As can be seen from the racemase dose-response curve, $1.1 \mu \mathrm{g}$ of racemase evoked a rate of about $120 \mathrm{nmol} / \mathrm{hour}$ (see Racemase curve in Fig. 1). The maximum rate of product produced (at maximum ligase concentration) would not be expected to exceed the rate of $\mathrm{D}$-alanine production at the concentration of racemase employed. On the basis of the ligase dose-response curve in this figure, about $6 \mu \mathrm{g}$ of the ligase preparation (approximately 450 munits) was selected for routine use in subsequent assays.

To determine the dependency of the rate of reaction on the dose of a mixture of both enzymes, the dose-response effect of a stock enzyme solution was tested (Fig. 2). Since the concentration of each enzyme in a series of coupled enzyme reactions determines the rate of its respective reaction when each enzyme is in a rate limiting concentration range (Fig. 1), changing the concentration of both enzymes simultaneously should affect the rate of final product formation in a non-linear, exponentiallike manner. That this occurs when coordinate changes in the concentrations of both the racemase and ligase were made can be seen in Fig. 2. From these results, about $4 \mu \mathrm{l}$ of this stock solution was used in the standard (routine) assay in the screen for inhibitors.

The time-course of dipeptide formation is depicted in Fig. 3. This experiment was run at $20 \mathrm{~mm}$ 
Fig. 4. The effect of L-alanine concentration on the velocity of the reaction. Concentrations of the enzymes are as in Fig. 3. $K m$ (app) refers to apparent $K m$. [S]: Substrate.

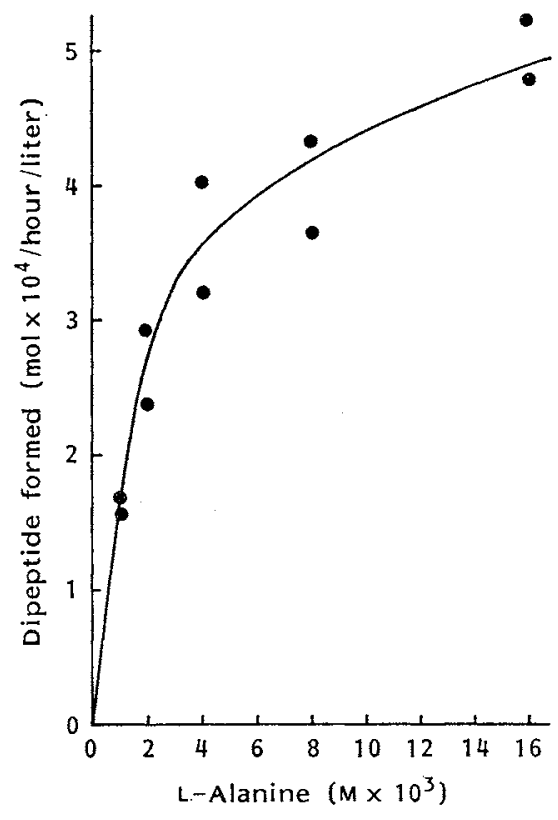

Table 1. Requirements for D-Ala-D-Ala synthesis from L-alanine in combination assay.

\begin{tabular}{lc}
\hline \multicolumn{1}{c}{ Additions } & $\begin{array}{c}\text { Activity } \\
\text { (nmol } \\
\text { dipeptide/hour) }\end{array}$ \\
\hline Complete system $^{\mathrm{a}}$ & 38.1 \\
Complete system $^{\text {(boiled) }}{ }^{\mathrm{b}}$ & 0 \\
Minus K $^{+}$ & 6.2 \\
Minus Mn $^{++}$ & 2.7 \\
Minus ATP $_{\text {Minus racemase and ligase }}$ & 0.8 \\
Minus racemase & 0 \\
Minus ligase & 3.3 \\
\hline
\end{tabular}

a Racemase $(0.67 \mu \mathrm{g}$ of protein preparation) and ligase ( $6 \mu \mathrm{g}$ of protein preparation) were included in $0.1 \mathrm{ml}$ of the "complete system" described in Materials and Methods.

b "Boiled" refers to use of boiled enzymes.

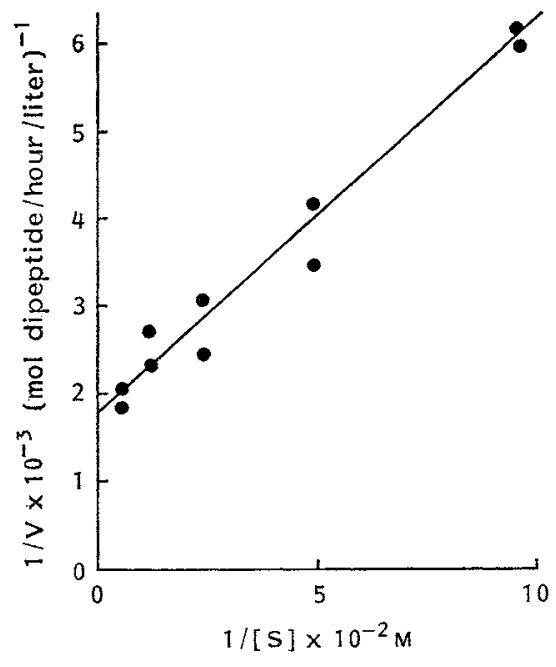

substrate as well as at $4 \mathrm{~mm}$ in order to help support the contention (noted in the discussion of Fig. 1) that $4 \mathrm{mM}$ of L-alanine is a limiting concentration of substrate at both high enzyme concentrations and long incubation periods. Although, as noted above, concentrations of substrate greater than $4 \mathrm{~mm}$ make it difficult to detect the ${ }^{14} \mathrm{C}$-labeled dipeptide product under inhibited conditions, the use of $20 \mathrm{~mm}$ L-alanine in the experiment in Fig. 3 was feasible because no inhibitors were included.

The experiment in Fig. 3 indicates that 4 mM substrate was limiting only at incubation times greater than 45 minutes. The rate of product formation continued unabated even after 2 hours of incubation when $20 \mathrm{~mm}$ substrate was used, while after about 90 minutes with $4 \mathrm{~mm} \mathrm{~L}$-alanine, little, if any, further product was formed. Interestingly, product formation appeared to proceed at an upward-sloping, rather than a linear rate, particularly at $20 \mathrm{~mm}$ substrate. This may be expected from an effectively low D-alanine substrate concentration made available to the ligase, relative to the high $\mathrm{Km}$ of the enzyme ${ }^{3)}$. According to this explanation, an initially small, but time-dependent increasing, amount of substrate for the ligase trickling in from the racemase reaction would explain the non-linear response.

On the basis of the results in Fig. 3 , an incubation time of 30 minutes was selected for the standard 
Fig. 5. Effects of DL-1-aminoethylphosphonic acid (AEP, $\triangle$ ), D-cycloserine (O) and 3-fluoro-D-alanine$2 d$ (FDA, on dipeptide formation in the combination assay.

The designated concentrations of inhibitors were incubated for 40 minutes with both enzymes prior to the 30-minute incubation with the complete mixture as described in Materials and Methods. Amounts of enzymes used are as in Fig. 3 except that they are included in the initial (pre-) incubation volume.

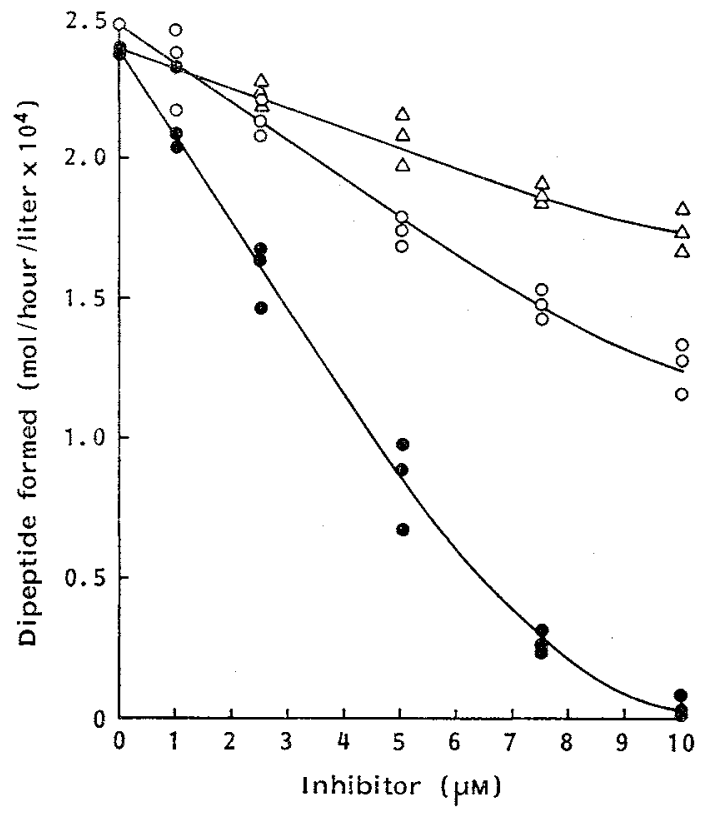

(routine) assay in subsequent experiments. Shorter time periods resulted in too small an amount of radioactive product to be reliably measured.

When the dependency of the rate of the overall reaction on the concentration of $\mathbf{L}$-alanine in the combined assay was determined, a hyperbolic-like dose response curve was obtained (Fig. 4). When these data were plotted on a doublereciprocal plot, a straight line was obtained. These data indicate a Vmax of approximately $5 \sim 6 \times 10^{-4} \mathrm{~mol}$ of dipeptide formed per hour per liter of incubation volume under these conditions. The concentration of substrate selected, on the basis of this experiment and upon the limitations imposed by the detectability of the ${ }^{14} \mathrm{C}$-dipeptide product as noted above, for use in subsequent routine assays ( $4 \mathrm{~mm}$ ) corresponds to about twice the approximate concentration required for half of the maximum velocity.

\section{Requirements for D-Ala-D-Ala Formation from L-Alanine}

The requirements for dipeptide formation from L-alanine as substrate in the combined assay are presented in Table 1 . There appears to be a slight, but significant, amount of each enzyme's activity remaining in the other's partially purified preparation. The requirements for $\mathrm{K}^{+}, \mathrm{Mn}^{++}$and ATP are consistent with those previously demonstrated by NeUHAUs ${ }^{3)}$ for dipeptide formation from D-alanine catalyzed by the ligase.

\section{Effects of Known Inhibitors}

The dose-response effects in the combined assay of compounds known to inhibit the racemase or both enzymes are shown in Fig. 5. These include DL-1-aminoethylphosphonic acid (AEP) and Dcycloserine, each of which inhibits both the racemase and the ligase ${ }^{2,12 \sim 18)}$ and 3-fluoro-D-alanine-2d (FDA), a potent racemase inhibitor ${ }^{2,6)}, *$.

It should be pointed out that these inhibitors were incubated with the enzymes for 40 minutes prior to the addition of L-alanine to initiate the reaction. This period of pre-incubation time was arbitrarily selected because it appeared to be a sufficient period of time that might be reasonably expected for an inhibitor to act in order for it to be of potential therapeutic value. To insure that ex-

* F. M. KaHAN (personal communication) has shown that the 2-deuterio (FDA) and protio forms of fluoroD-alanine exhibit equivalent inhibitory potencies in vitro on alanine racemase. WANG and WALSH ${ }^{2)}$ reported no kinetic isotope effect with FDA on the rate of inactivation of the recamase. KAHAN et al. ${ }^{3)}$ previously reported that the protio and 2-deuterio forms have equivalent in vitro antibacterial activity. 
tremely slow-acting inhibitors would not be missed or overlooked, longer pre-incubation periods could be used. It should also be noted that since the degree of inhibition or apparent potency of an inhibitor may be a reflection of the time of exposure of inhibitor with the enzyme(s), comparisons of the potencies of an individual inhibitor run at different pre-incubation times, or different inhibitors run for the same period of time, could be misleading. Moreover, since compounds such as AEP and cycloserine inhibit both enzymes, comparisons of the inhibitory data from the combined assay with those from assays of individual enzymes could also be misleading.

Nevertheless, it may be of value to note that after a 40 -minute pre-incubation period with the racemase, $2 \mu \mathrm{M}$ FDA in the specific racemase assay inhibited the enzyme by $50 \%$ (data were obtained from the individual racemase assays described in the Materials and Methods). In the combined assay, $3.8 \mu \mathrm{M}$ of FDA inhibited by $50 \%$. In the latter assay, the half-maximal inhibitory concentration of AEP was $40 \mu \mathrm{M}$ under the conditions described in Fig. 5, while for cycloserine this concentration was $25 \mu \mathrm{M}$. The $K i$ for AEP reported for the inhibition of the $E$. coli W racemase is $18 \mu \mathrm{M}^{11}$ and $800 \mu \mathrm{M}$ for the ligase ${ }^{13)}$. Inasmuch as both FDA and D-cycloserine have been found to be time-dependent, irreversible inactivators (i.e. suicide substrates) of the $E$. coli $\mathrm{B}$ alanine racemase ${ }^{2}$, no meaningful $K i$ values for these compounds against the racemase can be presented for comparison. However, NeuHaus and co-workers reported a $K i$ of $90 \mu \mathrm{M}$ for D-cycloserine against the ligase ${ }^{15)}$. Although, as noted above, these comparisons may be misleading, it suggests that the sensitivity of the combined assay is similar to that of earlier assays.

While various methods exist to test the effect of inhibitors or other enzyme effectors on alanine racemase or D-alanine: D-alanine ligase in separate assays of each of the enzymes, the method presented here represents, to our knowledge, the first one capable of detecting, i.e. screening for, such effectors of either or both enzymes in a single assay. The method is as simple and as rapid as previous assays of the individual enzymes.

\section{References}

1) Neuhaus, F. C. \& W. P. Hammes: Inhibition of cell wall biosynthesis by analogues of alanine. Pharmacol. Ther. 14:265 319, 1981

2) WANG, E. \& C. WALSH: Suicide substrates for the alanine racemase of Escherichia coli B. Biochemistry 17: $1313 \sim 1321,1978$

3) Neunaus, F. C.: The enzymatic synthesis of D-alanyl-D-alanine. I. Purification and properties of Dalanyl-D-alanine synthetase. J. Biol. Chem. 237: 778 786, 1962

4) Kollonitsch, J.; L. Barash, F. M. KAHAN \& H. KRopP: New antibacterial agent via photofluorination of a bacterial cell wall constituent. Nature 243: 346 347, 1973

5) Kollonitsch, J.: Novel methods for selective fluorination of organic compounds: Design and synthesis of fluorinated antimetabolites. Isr. J. Chem. 17: 53 59, 1978

6) KAHAN, F. M. \& H. KRopP: MK641/MK642 A fixed-ratio combination antimicrobial. 1 Rationale: The sequential blockade of bacterial cell-wall biosynthesis. Program and Abstracts of the 15th Intersci. Conf. on Antimicrob. Agents Chemother., No. 100, Washington, D.C., Sept. 24 26, 1975

7) KAHAN, F. M.; H. KROPP, H. R. ONISHI \& D. P. JACOBUS: MK641/MK642 A fixed-ration combination antimicrobial. 4 Advantages over the FA/CS prototype. Program and Abstracts of the 15th Intersci. Conf. on Antimicrob. Agents Chemother., No. 103, Washington, D.C., Sept. 24 26, 1975

8) Harris, D. A.; M. Ruger, M/A. Reagen, F. J. Wolf, R. L. Peck, H. Wallick \& H. B. Woodruff: Discovery, development and anti-microbial properties of D-4-amino-3-isoxazolidone (oxamycin) a new antibiotic produced by Streptomyces garyphalus n. sp. Antibiot. Chemother. 5: 183 190, 1955

9) Kuehl, F. A., Jr.; F. J. Wolf, N. R. Trenner, R. L. Peck, R. P. Buhs, E. Howe, I. Putter, B. D. Hunnewell, R. Ormond, G. Downing, J. E. Lyons, E. Newstead, L. Chaiet \& K. Folkers: D-4Amino-3-isoxazolidone, a new antibiotic. J. Am. Chem. Soc. 77: 2344 2345, 1955 
10) Lowry, O. H.; N. J. Rosebrough, A. L. Farr \& R. J. Randall: Protein measurement with the Folin phenol reagent. J. Biol. Chem. 193: 265 275, 1951

11) LAMBERT, M. P.\& F. C. NeuHAUS: Mechanism of D-cycloserine action: Alanine racemase from Escherichia coli W. J. Bacteriol. 110: 978 987, 1972

12) Atherton, F. R.; M. J. Hall, C. H. Hassall, R. W. Lambert, W. J. Lloyd \& P. S. Ringrose: Phosphonopeptides as antibacterial agents: Mechanism of action of alaphosphin. Antimicrob. Agents Chemother. 15: 696 705, 1979

13) Lacoste, A. M.; M. Poulsen, A. CAssaigne \& E. Neuzil: Inhibition of D-alanyl-D-alanine ligase in different bacterial species by amino phosphonic acids. Curr. Microbiol. 2: 113 117, 1979

14) Strominger, J. L.; E. Ito \& R. H. Threnn: Competitive inhibition of enzymatic ractions by oxamycin. J. Am. Chem. Soc. 82: 998 999, 1960

15) Neuhaus, F. C. \& J. L. LYNCH: The enzymatic synthesis of D-alanyl-D-alanine. III. On the inhibition of D-alanyl-D-alanine synthetase by the antibiotic D-cycloserine. Biochemistry 3:471 480, 1964

16) Neuhaus, F. C.: Selective inhibition of enzymes utilizing alanine in the biosynthesis of peptidoglycan. Antimicrob. Agents Chemother.-1967: 304 313, 1968 